\title{
The 2015 Proposal for an EU Directive on the Societas Unius Personae (SUP)
}

\author{
Another Attempt to Square the Circle?
}

Stephan Rammeloo*

\section{Introduction}

Stimulating business throughout the Single Market, not in the least for Small- and Medium-Sized Enterprises (SMEs), is one of the key priorities of the EU's ten-year growth strategy, 'Europe 2020'.' Empirical research, however, reveals hindrances, as notably SMEs find it (too) costly to be active across borders and only a small number of SMEs invest abroad. The reasons for this include the diversity of national legislations, in particular differences in national company laws, and the lack of trust in foreign companies among customers and business partners. ${ }^{2}$

These factors incited the Commission on 10 April 2014 to submit a proposal for a Directive on single-member private limited liability companies, making it easier to set up companies across borders between Member States. This should encourage more entrepreneurship and lead to more growth, innovation and jobs in the EU. The objective underlying the proposal is to facilitate cross-border activities of companies, by asking Member States to provide in their legal systems for a national company law form that would follow similar rules in all Member States and would have an EU-wide abbreviation - SUP (Societas Unius Personae). May 2015, however, the 2014 Proposal was superseded by a 'compromising text' ${ }^{3}$ 'This contribution aims at exploring the 2015 Proposal as it represents ius constituendum in its most recent form and compared to its 2014 'predecessor' Proposal. In order to be capable of comparing both singlemember company legislation projects, first the preliminary question must be answered: why sole-member companies deserve special notice from EU legislator (2),

* Associate Professor EU Company Law, Private International Law and Comparative Law, Maastricht University.

1. Explanatory Memorandum of the Proposal for a Directive on singlemember private limited liability companies, Brussels, 9 April 2014 $\operatorname{COM}(2014) 212$ final 2014/0120 (COD) (hereafter referred to as: EM 2014), p. 2

2. Ibid. For figures and facts on 'FDI' (Foreign Direct Investments) and barriers to be broken down, cf. Wuisman 2015, p. 34.

3. Council compromising text, Brussels, 21 May 2015, (OR. en) 8811/15 LIMITE DRS 39 CODEC 706, hereafter referred to as compromising text 2015. and, if so, to which extent this goal has been accomplished so far (3)? Under (4) the main substantive features of the proposed SUP Directive will be investigated, before and after the 2015 compromise. A brief summary of findings as regards the different concepts of the 2014 and 2015 Proposals will be rendered under (5). Under (6) overall conclusions are drawn.

\section{EU Law on Sole-Member Companies - Why?}

"Think small first". This adage heading the European 2008 Business Plan ${ }^{4}$ was in fact paid homage to by the Commission way back in time already. From the first global oil crisis in 1973 onwards, economic depressions culminated into the decline of many businesses, shake outs, scale enlargement and increasingly automatizing productions, resulting in alarming unemployment rates all over Europe. These developments incited the European Commission to invest in law, making capable of stimulating the creation of 'new' jobs, preferably 'just around the corner' and to be 'produced' by SMEs, perhaps even more than by large industries.

From 1989 onwards, the so-called '12th EU Company Law Directive' regime obliged EU Member States to provide for a private limited liability company that could be set up by business risk-taking individual entrepreneurs on their own (id est by one single member). ${ }^{5}$

At that time, SMEs however still mainly conducted business on a domestic scale, as the CJEU judicature on cross-border freedom of establishment still had to be awaited. To date, the Commission underscores two additional factors requiring adequate response thereto and renewed action by EU legislator.

In the first place companies, taking profit from the CJEU judicature from the late 1990s of last century onwards favouring cross-border company movement and

4. 'Think Small First': A Small Business Act for Europe, IP/08/1003, Brussels, 25 June 2008.

5. Before not all Member State laws allowed for single-member private limited liability companies (cf. company as a nexus of contract, at least requiring two founders/members). The main features of the "12th EU Company Law Directive' being a predecessor of the SUP Directive will be set out below (3.1) briefly. 
enhanced freedom of establishment ${ }^{6}$ tends 'to go abroad' more and more. As moreover empirical research reveals that SMEs involved in international economic conduct report stronger turnover growths, job creation and innovative force than SMEs remaining 'just around the corner', the follow-up of the 12th Directive should facilitate cross-border business of SMEs. ${ }^{7}$

Second (and closely interrelated to the first factor), the Commission while adhering to the Reflection Group's views ${ }^{8}$ is convinced that a simplified template for singlemember companies across the EU should as well allow for single shareholder start-ups and holding companies with wholly omned subsidiaries to reduce transaction costs and avoid unnecessary formalities. ${ }^{9}$ The Commission in other words embraces the importance of SMEs equally operating as stand-alone business or embedded in a company group structure.

\section{EU Law on Sole-Member Companies - How?}

\subsection{Harmonization of Member State Laws - The} '12th EU Company Law Directive'

Article 50 subsection 2(g) TFEU forms the legal basis for harmonizing EU Member State company laws with a view to creating safeguards for 'company members and others'. The already mentioned EU Directive 89/667/ EEC of 21 December 1989 on single-member private limited liability companies may well be considered as 'first-generation' EU law fostering SMEs. This '12th EU Company Law Directive' regime ${ }^{10}$ allows entrepreneurs to create a limited liability regime for private companies having one single member (Article 2.1), be it under the restriction (Article 2.2) that Member States are (still) allowed to lay down special provisions or penalties for cases where (1) a natural person is the sole member of several companies or (2) a single-member company or any other legal person is the sole member of a company. The 'single-member right' was counterbalanced by various safeguards (Article 3: registration requirements; Article 4: resolution making recorded in minutes or drawn up in writing; Article 5: contracts between the sole member and his company as represented by him (conflict of interests; Selbstkontrahieren) shall be recorded in minutes or drawn up in writing). Pursuant to Article 6, where a Member State allows singlemember companies as defined by Article 2(1) in the case of public limited companies as well, the Directive equally applies.

C-212/97 (Centros); C-208/00 (Überseering); C-167/01 (Inspire Art Ltd.); C-210/06 (Cartesio); C-378/10 (Vale).

7. OECD 2009 and EM 2014, p. 3.

8. The 2011 Report of the Reflection Group. Available at: <http://ec. europa.eu/internal_market/company/docs/modern/reflectiongroup_ report_en.pdf>.

9. EM 2014, pp. 3-4.

10. This Directive was replaced by consolidating Directive 2009/102.
Pursuant to Article 29(1) of both the 2014 and 2015 compromising texts of the SUP Proposal Directive 2009/102 will be repealed. The concept of the latter yet remains relevant as Part I of the proposed SUP Directive more or less 'duplicates' the essential provisions of this '12th Company Law Directive' ( $c f$. further below).

\subsection{From Harmonization of Member State Laws to Uniform EU Law - The SPE Unvollendete}

Whereas the 12th EU Company Law Directive did not go beyond harmonizing national laws of the Member States having regard to the formation of private limited liability companies by one single member, from the year 2008 onwards various efforts were undertaken to reanimate the concept of a fullyfledged European private limited liability company. The idea for an exhaustively and coherently worked out 'European Ltd.' was already launched in 1973 by Bouchourevliev. ${ }^{11}$

To cut a long story short: although no less than three successive draft proposals for an EU Regulation providing for a Societas Privata Europaea (SPE) saw the light, ${ }^{12}$ the SPE project ultimately failed as a consequence of the fact that 'traditional' disparities concerning capital requirements, board structures and employee involvement until today divide the Member States. ${ }^{13}$

\section{Proposal for a Directive - Societas Unius Personae (SUP)}

\subsection{Institutional Basis; Overarching Structure of} Directive

The concept of a fully fledged 'European' private limited liability 'format' having been relinquished or at least being postponed for the time being, ${ }^{14}$ the 2014 Proposal for a Directive on the Societas Unius Personae (SUP) ${ }^{15}$ as amended by the compromising text from 21 May 2015 now endorses a concept whereby companies (1) duly established under the national law of any Member State $^{16}$ and (2) complying with preconditions enshrined in Part 2 of the Directive are rewarded with a European 'brand' to increase trustworthiness. ${ }^{17}$ Correspondingly, the Commission opted for another institutional basis, namely the aforementioned proviso of Article 50 subsec-

11. Bouchourevliev 1973

12. For a kaleidoscope view of the SPE legal 'history' between 2008 and 2013, cf. Zaman et al. 2009 and Hirte \& Teichmann 2013.

13. Proposal for a Council Regulation on the Statute for an European private company, $\operatorname{COM}(2008) 396$. The withdrawal of the SPE Proposal was announced in the Annex to the Communication on 'Regulatory Fitness and Performance (REFIT): Results and Next Steps', COM(2013) 685, 2 October 2013.

14. EM 2014, p. 4: "Most participants stressed that [...] the efforts towards the SPE should continue"

15. For comments (however, still related to the 2014 Proposal), cf. Lutter \& Koch 2015.

16. With EEA relevance.

17. Article 6 subsection 1: " $[\ldots]$ the possibility of establishing private singlemember limited liability companies in the form referred to as SUP". 
tion 2 instead of Article 352 TFEU, the latter provision requiring unanimous decision making.

The overarching structure of the 2014 Proposal for a Directive remained unaffected by the 2015 compromising text. The first 'layer' is formed by Part 1 'General Provisions'. Part 1 mutatis mutandis 'recodifies' the regime of the 12th EU Company Law Directive. It regulates (Articles 1-5) scope; disclosure; general meeting and decisions of the single member; and contracts between the single member and the company. ${ }^{18}$ The 'layer' of Part 2 provides for 'brand new' provisions under the heading Societas Unius Personae. Provided that sole-member companies comply with Chapters 1 (General principles and legal form), 2 (Formation), 3 (The instrument(s) of constitution) for an SUP, 3a (Information available to the founder), 4 (Registration), 5 (Single share), 6 (Share capital) and 7 (Organization), such companies may register as 'SUP'. Part 3, containing 'Final provisions', is followed by Annex 1, listing the 'types of companies referred to in Article 1.1(a)'.

The compromising text 2015 differs from the initial 2014 Proposal in that it:

- provides for a whole set of guarantees related to online registration;

- $\quad$ is without prejudice to anti-money laundering rules (and even improves them);

- leaves the question of seat of companies to national laws; and

- allows Member States to control distributions and to oblige companies to build up legal reserves. ${ }^{19}$

Promising as this overall concept thus at first sight may seem, it is beyond doubt that unlike an EU Regulation ( $c f$. the Proposal for the SPE), an EU Directive harmonizing national laws eo ipso is incapable of providing for an exhaustive 'codification' in the field concerned. This observation may serve as a starting point for further treatment of the proposed text.

\subsection{Substantive 'Scope'}

As has been described above, the proposed SUP Directive is structured in a complementary manner: Article 1 submits both "types of companies referred to in Annex 1 " and "the Societas Unius Personae (SUP) referred to in Article 6 to Part 1 of the Directive", thus acknowledging the right, existing under the 12th Directive, to set up private company types by one single member. Part 2 of the Directive (Article 6) "shall (only, SR) apply to the laws, regulations and administrative provisions of the Member States relating to the possibility of establishing private single-member limited liability companies in the form referred to as SUP".

Member States shall inform the Commission of any changes' to companies referred to in the Annex under their national laws. Once under their national laws Member States allow other companies to be singlemember companies, Part 1 equally applies.
Although allegedly "the Proposal does not introduce a new legal form at European level, a so-called '29th regime',"20 the wording is somewhat misleading, as to date already more than 28 Member States private limited liability company 'formats' exist. ${ }^{21}$ French law, for example, provides for no less than four business private limited-like 'modalities': apart from the sàrl as mentioned in the Annex, SNEs may opt for the EURL and the SASU, even apart from the option of the EI and the entreprise individuelle, offering limited liability to individuals (i.e. not legal persons). ${ }^{22}$ It remains unclear, though, whether French legislator may endow each of these modalities with the 'name tag' SUP, and, if so, whether the Commission should be informed or whether subsection 3 allows for this option directly. ${ }^{23}$

\subsection{Formal 'Scope'}

As regards the formal scope (i.e. the geographical reach), the 2015 compromising text leaves the reader of the initial 2014 Proposal uncertain. As observed above (under 2), one of the additional reasons to elaborate the SUP Directive is that as a 'follow-up' of the 12th Directive it should facilitate cross-border business of SMEs. Article 10 of the 2014 Proposal reads:

An SUP shall have its registered office and either its central administration or [italics, SR] its principal place of business in the Union.

From the outset, it is clear that the three traditional connecting factors - registered office, central administration ('headquarters') or 'principal place of business' coincide with those taken up in Article 54 TfEU. This provision thus covers a wide range of Tatbestände (fact constellations) that may even extend to the involvement of third legal orders. One may, in that respect, think of the following examples (non-exhaustive overview):

i. Starting point is the 'purely domestic' case of a Dutch Besloten Vennootschap (BV) deciding to convert itself into an SUP (Article 9), all three connecting factors mentioned remaining situated in the Netherlands;

20. Commission Memo, Brussels, 9 April 2014, under referral to IP/14/396 and MEMO/14/275.

21. Cf. for an overall impression of 'business formats', all over Europe is still up to date: Herberstein 2001. In most Member States, no troubles show, as, for example, deregulation tendencies did not result in a brand new company type (cf. the Netherlands: the 'Flex BV' provides for legal continuity as it does not introduce another private limited liability company). Cf., however, below.

22. It is thus even possible to secure protection of the family home and other non-business property, from creditors through a declaration d'insaisissabilité, which you can get through a notaire (notary public).

23. It is beyond doubt, so far, that French legislator aims at maintaining the French 'business formats' alongside the SUP: “(...) réserver le champ de la proposition de directive aux seules EURL. C'est un point essentiel: en aucun cas, la SASU ne devrait être affectée par ce nouveau dispositif (the SUP, SR) pour préserver la liberté contractuelle qui lui est propre", Les rapports de la Chambre de Commerce et d'industrie de région Paris-Ile-de France. Available at: <www.cci-paris-idf.fr/sites/default/files/ etudes/pdf/documents/societes-unipersonnelles-proposition-dedirective-synthese.pdf> (last visited 30 October 2015). 
ii. The BV could as well opt for conversion into an SUP with, after, registered office, central administration and principal place of business residing in Germany;

iii. The BV retains its registered office in the Netherlands, while having both its central administration and principal place of business in Belgium;

iv. The BV might as well, after conversion into an SUP, having exclusively its registered office in the Netherlands, its central administration in Germany and its principal place of business in a non-EU legal order. ${ }^{24}$

In 2014 the Commission still held that "to enable businesses to reap the full benefits of the internal market, Member States should not require that an SUP's registered office and its central administration be necessarily located in the same Member State". ${ }^{25}$ The compromising text 2015 , however, altogether skipped Article 10 as well as the corresponding Recital 12 with a cryptic one liner: "[P]rovisions on the seat have been deleted by the Presidency. This leaves unchanged the current legal situation". ${ }^{26}$ There is no 'current' legal situation, however, in the sense that the SUP does not yet exist. More likely is that the drafters had in mind to refer to the aforementioned CJEU judicature having regard to inbound and outbound migration modalities for those companies being 'creatures of national law' - the SUP remaining such a creature as well.

\subsection{Formation}

The initial 2014 SUP Proposal and the compromising text 2015 both underscore the importance of a swift incorporation (and registration, $c f$. further below) throughout the EU territory. ${ }^{27}$ Setting up an SUP will be possible either ex nihilo (Article 8) or by conversion (Article 9) of an already existing private limited liability company as referred to in Annex 1 . With a view to the 2014 Proposal, the Commission left it to the Member States to introduce the SUP, either as an exclusive business format replacing national private company types or as complementary business format alongside the already existing private limited liability companies. ${ }^{28}$

For more than just one reason, the former option seems inadequate. First, the 2015 Proposal has been curtailed considerably, notably in view of the functioning of general meeting and company board(s). It would thus hardly be feasible to 'replace' national Member State laws on close corporations; second, it would not be recommendable, as private companies would have to convert themselves into an SUP; third, if SUP would want more

The 'outer boundary' may appear to be CJEU C-196/04 (CadburySchweppes), requiring 'genuine ties' with the Single Market (briefly summarized: required is economic and physical presence, not only a 'letter box' company).

25. EM 2014, p. 3.

26. Compromising text 2015, p. 5

27. The Commission Memo, Brussels, 9 April 2014, emphasizes the importance of a 'swift formation': potential savings 'cost-cutting' via SUP: approximately $€ 230-€ 650$ million in (just) one year.

28. Commission Memo, Brussels, 9 April 2014. shareholders, it could not convert into a private company any longer, but it would have to convert that company into a public limited liability company.

Business structuring possibilities have been widened to the extent that Article 8 subsection 1 of the compromising text 2015 not only allows 'natural' or 'legal' persons to set up an SUP but also, "if allowed by national law of the Member State of registration, an SUP may also be incorporated by other entities not having legal personality". Thus, the SUP may find itself embedded in a 'group' structure, its single share being held by e.g. a commercial partnership. ${ }^{29}$

\subsection{Registration}

In view of the 2014 Proposal, the Commission still observed:

[...] the registration procedure form the main part of this Directive (is) a critical issue in facilitating the establishment of subsidiaries in EU countries other than the home country of the company. The Directive requires Member States to offer a registration procedure that can be fully completed electronically at a distance without requiring the need of a physical presence of the founder before the authorities of Member State of registration. It must therefore also be possible for all communication between the body responsible for registration and the founder to be carried out electronically. The registration of the SUP must be completed within three working days in order to allow companies to be formed quickly (Article 14$){ }^{30}$

Yet, the original provision of Article 14 (a registration period not exceeding three days) turned out to be overambitious. In particular, the SUP registration "at a distance without requiring the need of a physical presence" raised foreseeable concern. SMEs being stimulated to go abroad, thus no longer operating "just around the next corner" may well engender abuse, in twofold respect. The costs to start legal actions against malperformance by an SUP may discourage those entering into transactions with a "remote" SUP. Apart from this, there is also the risk of "company hijacking". ${ }^{31}$ Rather than

29. Cf. the notion of a $\mathrm{GmbH} \&$ Co. KG under German law, the Proposed Directive potentially also allowing for a SUP \& Co. KG? The Recital of the compromising text 2015 remains completely silent on the widened functional reach of Article 8 subsection 1 .

30. EM 2014, p. 7. Cf. Ries 2015, p. 65 et seq. and Hommelhoff 2015, p. 69 et seq.

31. Companies House recommendation: self-control by companies against third persons registering as 'company representatives' <www. companieshouse.gov.uk>. For detailed treatment of the whole wide range of registration tools available under EU law and comments thereto by commerce chambers in all Member States, cf. Wuisman 2015, p. 34. 
being 'trustworthy', an SUP may thus on the contrary raise suspicion. ${ }^{32}$

These concerns begging for action, the 2015 compromising text is amended considerably. The newly drafted provisions of Article 14 and ff. aim at achieving "a whole set of guarantees related to on-line registration". 33 In line with the recommendations set out in the European Commission's 2011 Review of the Small Business Act to reduce the start-up time for new enterprises, national authorities should now make an effort to complete the on-line registration process within five working days, ${ }^{34}$ in case, national templates for registration and for the instrument(s) of constitution which are available online are used, unless there are exceptional circumstances, such as, in particular, the complexity of the case which requires a special examination in the context of registration, that would make it impossible to comply with this deadline. The deadline for completion of the registration process should be counted from the moment when the registration authority receives a complete application, including any necessary supporting documentation and a confirmation that all necessary fees for registration have been paid. ${ }^{35}$ To ensure a high level of security and trust, in the context of on-line cross-border identification of the founders of the SUP, electronic identification means issued in another Member State and notified to the Commission, in accordance with Regulation (EU) No. 910/2014, should be accepted by the authorities of the Member State of registration. In addition, that Member State may recognize other electronic and non-electronic identification means. If, for the purpose of registration, the registration authorities recognize non-electronic identification means issued in the Member State of registration, they should also rec-

32. This feature may enhance creditor 'fore-checking' measures, notably the stipulation of rights in personam/in rem? Call for harmonization security rights (pledge) clashes. The downside thereof is that limited liability as a principle is under pressure. Furthermore may 'creditor selfhelp' result in a more advantageous position of large (influential) creditors, at the detriment of involuntary and 'powerless' SUP creditors (expected: individuals, customers, making uses of services rendered by the SUP).

33. Compromising text 2015, Recital 15e: Member States should be able to request by registration, more information, from the founders which is outside the scope of this Directive, in particular for tax, social, antimony laundering and other purposes.

34. It must be realized that any 'delay' of two days (registration: from a three to a five days' period) may appear to make a difference to UK SMEs planning to incorporate or to convert into an SUP with registered office in the UK. Registration of an SUP 'on the continent', however, will hardly result in 'measurable' time gains, as in many Member States, the formation of an SUP, after all remaining a 'creature of national (Member States) laws' often requires the involvement of e.g. a notary public.

35. Ibid., Recital 16. Furthermore, provisions concerning the establishment of SUPs should not affect the right of Member States to maintain existing rules or enact new rules concerning possible verification of the legality of the registration process, including rules on the verification of identification and legal capacity in order to provide for safeguards for the reliability and trustworthiness of registers. Such rules may include, for example, the legality check via a video-conference or other on-line means that provide a real-time audio-visual connection. ognize the same type of identification means issued in other Member States. ${ }^{36}$

\subsection{Single Shareholder}

Chapter 5, containing one provision (Article 15), in a way builds further on the fundaments of the 12th EU Company Law Directive as it equally endorses the 'single share' principle. As this principle reflects the very essence of the SUP, the wording of Article 15 is rendered in full here:

1. An SUP shall not have more than one share. This single share shall not be split. 2. An SUP shall not, either itself or through a person acting in his own name but on the SUP's behalf, acquire or own its single share. 3. Where in accordance with national law, a single share of an SUP may be owned by more than one person, those persons shall be regarded as the single-member of the SUP. They shall exercise their rights through one representative and shall notify the management body of the SUP, without undue delay, the name of that representative and the name of the co-owners and any change thereto. Until such notification, the exercise of their rights in the SUP may be suspended in accordance with national law. The identity of the representative shall be recorded in the relevant register or be entered in a register kept by the company and accessible to the public.

Over the past three decades, legal practice hardly experienced troubles with the sole-member concept for private limited liability companies. ${ }^{37}$ As the single share is the very fundament of the SUP, it does not make sense to question the possibility of shares without voting rights or without dividend rights. In the light of the prescription that "the single share shall not be split", it does make sense, however, to ask whether depositary receipts (certificering van aandelen) as existing under the Netherlands company law are compatible with the SUP regime. Tentative reasoning, namely that the SUP remains a 'creature of national law', does not provide for an answer here, as the concept of such 'receipts' seems not compatible with the approach followed by the Directive. ${ }^{38}$ Other matters, notably having regard to the SUP's internal organization and its position as a group member, will be dealt with below. ${ }^{39}$

\subsection{Share Capital}

Chapter 6 of the compromising text 2015 on 'Share capital' has been curtailed considerably in comparison to

36. Ibid., Recital 18a.

37. Unlike cross-border company migration, the 12th Company Law Directive never gave raise to preliminary proceedings in the CJEU.

38. Neither does the compromising text 2015, p. 21, note 8 provide for a helpful guideline: 'Remark for lawyers linguists - In many Member States, different words are used for shares depending on whether shares are mentioned in the context of private or public limited liability companies. Some Member States use the term 'participation' for shares in private limited liability companies. The difference between private and public limited liability companies is not connected with the ownership structure in any way (private or public).'

39. Cf. 4.8 and 4.9 below. 
the initial 2014 Proposal. ${ }^{40}$ One could say that as a consequence of this curtailment, national law is creeping in in the SUP Directive concept through the backdoor again, as the regime of the so-called ' 2 nd EU Company Law Directive' as consolidated to date in Directive 2012/30 is reserved for public limited liability companies only.

Although substantively speaking, no minimum (formation) capital is required (Article 16 subsection 1), ${ }^{41}$ a 'number' of 1 euro has been set as a threshold, for the reason that limited liability companies cannot operate without a 'general meeting' of at least one shareholder having one share. A maximum value of this sole share may, on the other hand, not be prescribed by Member State laws either (Article 16 subsection 3). Pursuant to Article 16 subsection 4, Member States may require the SUP to build up legal reserves as a percentage of the profits of the SUP and/or up to the amount of minimum share capital required for private limited liability companies listed in Annex I. Member States shall allow companies to build reserves. This is without prejudice to an obligation to include reserves, if any, in the presentation of the balance sheet in accordance with Article 10 of Directive 2013/34/EU and any disclosure obligations relating to reserves laid down in national laws. Quite remarkably, in view of a loss of transparency, the compromising text 2015 relinquished the initial proviso of Article 16.5:

Member States shall require letter and order forms whether in paper form or in any other medium, to state the capital subscribed and paid up. If the company has a website, that information shall also be made available on it.

Article 17 on 'consideration' also yields to national law, as no longer contribution in cash and in kind is acknowledged, the latter payment mode only remaining inasmuch allowed for under national law of the Member State where the SUP is registered. ${ }^{42}$ In one respect, though, the compromising text 2015 is more severe than the 2014 Proposal as, pursuant to Article 16 subsection 4

[w]ithout prejudice to paragraph 1, Member States may require the SUP to build up legal reserves as a percentage of the profits of the SUP and/or up to the amount of minimum share capital required for private limited liability companies listed in Annex I. ${ }^{43}$

40. Cf. Schmidt 2015, p. 1 et seq.

41. Leuering 2015, p. 89 et seq., however stresses that any capital requirement as part of the whole SUP's 'formation process' is a 'mere drop in the ocean'.

42. No attention is given to Nebenleistungen (i.e. obligation imposed on shareholders other than consideration for shares). On the basis of tentative reasoning, namely that the SUP remains a 'creature of national law', this should be possible.

43. Article 16 subsection 4 in 2014 still reads: 'Member States shall ensure that the SUP is not subject to rules requiring the company to build up legal reserves. Member States shall allow companies to build reserves in accordance with their articles of association.'
Article 18 subsection 1 on contributions is flaunting the imperfection by its vagueness:

Member States shall ensure the establishment of mechanisms in national law that would prevent SUPs from being unable to pay their debts after making distributions.

It replaces the 2014 proviso:

An SUP may, on the basis of a recommendation from the management body, make a distribution to the single-member provided that it complies with paragraphs 2 and 3.

The latter subsections as well are redrafted as such that they leave 'control' over distributions more to Member State laws. Article 19 on the 'Recovery of distributions wrongfully made' and Article 20 on 'Share capital reduction' have even been deleted entirely, be it that pursuant to Article 18 subsection 6 of the compromising text 2015:

Member States shall require that any distributions, or share capital reductions leading to a distribution to the single-member made contrary to this Article, are refunded to the SUP.

\subsection{Organization}

Explanations for the SPE failure as set out ${ }^{44}$ re-show: whereas quite daringly the initial 2014 Proposal for an SUP Directive still contained various provisions on the competences of the general meeting and company board(s), the compromising text 2015 is featured by the curtailment, or, even more, the overall abolishment of provisions concerning the company's organization: Article 21 (involvement of the single member) in the company's resolution making process, ${ }^{45}$ Article 23 (shareholder instruction) ${ }^{46}$ and Article 24 (representation powers) are all fully deleted. Not even considered, from the outset onwards, was the elaboration of a set of rules on accountability and liability of company officers. ${ }^{47}$

Notwithstanding the 'back up' of some Company Law Directives harmonizing national Member State laws the matter of e.g. company law representation has been properly harmonized and the initial proviso of Article 24

44. Cf. 3.2, above.

45. What remains is Article 4, kicking in open doors: Subsection 1: "The single-member shall exercise the powers of the general meeting of the company"; subsection 2: "Decisions taken by the single-member in the field referred to in paragraph 1 shall be recorded in minutes or drawn up in writing and kept for at least five years. Member States may provide that it is sufficient for the decisions to be stored electronically by the company, in a safe and accessible format preventing the loss of integrity of decisions. Member States may also provide that decisions must be kept for a longer period than five years".

46. Cf. also the delicacy of this topic in view of SUPs embedded in group structures (4.9, below).

47. Way back in time, the attempt for a '5th EU Company Law Directive' on the functioning of organs of limited liability companies already failed. Ever since, the law governing the functioning of company organs appeared to be a 'no-go area' for EU legislator. 
had no real surplus value ${ }^{48}$ - the substantive value of the SUP Directive inevitably devaluated.

From point of view of matters other than company law, the compromising text 2015 also commits itself to 'selfrestriction', as:

[t]his Directive is without prejudice to any national laws governing matters outside its scope, such as matters related to labour law, posting of workers, workers' participation in the management or supervisory bodies of companies, right to information and consultation, taxation, accounting or insolvency proceedings (Article 7(4) and Recital (10a)). ${ }^{49}$

Relevance and weight of this self-restriction show even more if one realizes that there is no 'ceiling' on the use of SUPs. SUPs may, in other words, serve SMEs as well as bigger 'firms'.

The intermediate conclusion can therefore be no other than that it does not seem to make sense any longer to let the SUP replace national private limited liability company 'formats'. Even worse, the abolishment of provisions substantively formulating powers bears an impact not solely on SUPs operating as 'stand-alone' business units but also on those SUPs involved in group or chain structures.

\subsection{Company Groups - Company Chains}

Article 8 of the initial 2014 Proposal according to which "[a]n SUP may be incorporated by a natural or legal

[italics SR] person" firmly showed in favour of the option for SUPs to be embedded in a company group structure, ${ }^{50}$ either as subsidiary or as parent company. The wording of the same article of the compromising text 2015 even widens the range of group options:

[i]f allowed by national law of the Member State of registration, an SUP may also be incorporated by other entities not having legal personality [italics SR]. ${ }^{51}$

The Recital of the compromising text 2015 takes a far less firm, not to say even ambiguous position, though:

[h]owever, Member States should be able to prohibit an SUP from being a single-member in another limited liability company in cases of cross or circular ownership, in particular in order to prevent situations where an SUP, indirectly, holds its own share, either in a situation where companies hold shares in each

48. According to the compromising text 2015, Recital 10a, Directive 2009/101 (1st Company Law Directive) is (analogously) applicable. This instrument covers company representation, pre-incorporation stage and company nullity (exhaustive grounds and procedural safeguards).

49. Compromising text 2015, p. 5. For consequences as regards the 'outer boundaries' of the Directive, $c f$. below (4.10).

50. EM 2014, p. 2: '(...) costs (including the additional necessary legal advice and translation) are likely to be particularly high for groups of companies, since any parent company, and particularly an SME parent, is presently faced with different requirements for each country in which it wishes to establish a subsidiary.'

51. Cf. (commercial) partnerships, as referred to above. For an overview of the SUP potential, cf. Teichmann 2015, p. 37 et seq. other, or where more than two companies holding shares in each other in such a way that the last company in the chain ${ }^{52}$ holds the single share of the SUP. Outside the SUP framework Member States should remain entitled to restrict the chain of companies by not allowing single-member companies to be the single-member in other companies. ${ }^{53}$

One may thus well ask what remains of the wording of Article 8 and the aim endorsed by EU legislator to facilitate group structures.

This strategic 'withdrawal' is explainable, as it clearly echoes failed attempts that date back to the early 1980 s of last century to harmonize the laws of the EU Member States on company group structures via a Draft Proposal for a '9th EU Company Law Directive'. ${ }^{54}$ Ever since, the topic of company groups is reputed, not to say notorious for its delicate nature: EU legislator is extremely reluctant to enter this (no go?) area, even when definitions are explicitly restricted for the use of other than company law-related matters ( $c f$. for the new accounting Directive regime only). ${ }^{55}$

From this perspective, it is comprehensible but at the same time quite ironic that, the 2014 Proposal still underscoring that "the SUP may be an attractive model for groups of companies and the Directive therefore allows the single member to give instructions to the management body", ${ }^{56}$ Article 23 ("The single-member shall have the right to give instructions to the management body") ${ }^{57}$ has been radically removed from the compromising text 2015.

Meanwhile, the mere circumstance that national laws of several Member States may be expected not to prohibit single-member companies SUPs be involved in group structures, either as a parent or subsidiary, even more in a cross-border context, ${ }^{58}$ opens Pandora's box in respect of many company group-related legal matters. One may think of, inter alia, the issue of conflicting interests between parent and subsidiaries, the 'reach' of instruc-

52. In the context used here a 'vertical' chain construction is meant. 'Horizontal' chain structures may as well show (one shareholder possessing the single share in a series of SUPs). As both the 2014 and 2015 texts remain silent on this subject-matter, national laws are likely to apply, the SUP after all remaining a 'creature of national law' endowed with SUP 'brand'.

53. Recital 11 of the compromising text 2015.

54. Draft Proposal for a Ninth Council Directive pursuant to Article 54(3)(g) of the EEC Treaty relating to links between undertakings and in particular to groups, text available at: <www.mhc.ie/uploads/9th_proposal. $\mathrm{pdf}>$.

55. Sǿgaard 2014.

56. EM 2014, p. 8.

57. EM 2014, p. 13 still reads: 'In order to facilitate the operation of groups of companies, instructions issued by the single-member to the management body should be binding. Only where following such instructions would entail violating the national law of the Member State in which the company is registered, the management body should not follow them.'

58. The 'simple' removal of Article 10 on the SUP 'seat' from the initial 2014 Proposal (cf. above, 4.3) does not prevent SUPs from being involved in the laws of different legal orders, by having either their registered office, central administration and/or principal place of business in different EU Member States. 
tion powers by the general meeting and limitations thereto, the position of disqualified company officers, the 'business judgement rule' and, last but certainly not least (parental) liability schemes. ${ }^{59}$ The ongoing and ever increasing entanglement of business conglomerates throughout the Single Market leaves the EU legislator no other option than to reanimate attempts to structure legal notions on company groups and chains. ${ }^{60}$

\subsection{0 'Left Outs' - National Law 'Creeping in' in Directive Proposal}

Perhaps even more important than the matters included in the SUP Directive are the 'left outs'. Whereas until 2013, the draft SPE EU Regulation still strived for a 'uniform' EU business format, the SUP EU Directive does not reach beyond the aim of complementing national laws, ${ }^{61}$ having regard to private limited liability companies referred to in Annex 1. Regulations not even being capable of covering (exhaustively) all company law-related disputes ${ }^{62}$ this observation applies a fortiori to the legal instrument of a Directive.

How, in other words, can - and must - the 'outer boundaries' of the proposed SUP Directive be delimitated, to which law(s) must 'matters excluded' therefrom be submitted, and, last but not least, in how far may the restricted substantive scope of the compromising 2015 text be expected to be problematical in everyday practice?

With a view to answering these questions, a clear distinction must be drawn first between matters that ratione materiae speaking are deemed 'organically' to be captured by the substantive 'scope' of the 'proper law of the company', yet not being 'harmonized' in satisfactory manner by the SUP Directive. One may think of (cf. above, what has been ascertained) inter alia, powers of company organs, the internal accountability and external liability of company officers, the internal and external affairs of stand-alone operating companies as well as company groups.

Matters not captured by the 'functional' scope of the proper law of the company, one could say the real 'left outs', may nevertheless be entangled with and likely to affect company relationships (in)directly. One may think of e.g. labour law co-affecting the position of company officers, tax law, insolvency law inasmuch relating

59. Striking example of complications arising from cross-border company group structures, excepting a (French) parent company from liability that would have applied to a 'non-foreign' (Portuguese) parent can be taken from CJEU C-186/12 (Impacto Azul).

60. Recently, this challenge has indeed been taken up again by the Forum Europaeum on Company Groups, "Proposal to Facilitate the Management of Cross-Border Company Groups in Europe", ECFR 2015, p. 299

61. The initial concept of setting up an SUP ex nihilo no longer looks realistic (cf. observations made on the abolishment of substantive law oriented provisions).

62. For comparative lawyers, this is a well-known phenomenon: 'uniform' law (einheitliches Recht; loi uniforme) is like any law 'embedded' in law in general, as a consequence of which on the occasion recourse to national law is inevitable (cf. the Vienna Sales Convention 1980 on international commercial sale contracts. This convention being uniform law, 'bordering' issues like e.g. limitation statutes remain to be submitted to national laws). to the company officers' accountability or the company's liquidation process, etc., but also the liability of company officers inasmuch not company law but tort law biased. Understandably, the demarcation line between both categories ultimately depends on the qualification (also referred to as 'conflicts of law characterization') in court and may appear to be rather thin in everyday practice.

In how far are the restricted substantive 'scope' and the 'characterization' of disputes at stake turn out to be problematical in practice? For a proper answer to this question it must be borne in mind that in a purely domestic context as in the 'beginning days' of the 12th Company Law Directive, the issue of 'characterization' hardly ever showed, as after all irrespective of how the issue at stake was qualified the national laws of the Member State where the single-member company had both its registered office and headquarters and principal place of business applied anyway. The conflict of laws problem of 'characterization' was, in other words, mostly absorbed.

As observed above, however, things are likely to change considerably when future SUPs, endorsing the incitement of the Commission to go abroad, show cross-border ties by having their registered office, central administration and/or principal place of business in different EU (or, perhaps even non-EU) legal orders.

Whereas the initial 2014 Proposal did not contain an explicit provision, the Explanatory Memorandum observing that "where a matter is not covered by this Directive, relevant national law should apply", 63 the compromising text 2015 devotes an extended provision to the substantive 'borders' of the proposed Directive. Proper treatment requires that Article 7 subsection 4 is rendered in full.

An SUP shall be governed (a) by national laws adopted by the Member State in which the SUP is registered in order to comply with this Directive, and, (b) in case of matters not regulated by this Directive, by national laws applicable to private limited liability companies limited by shares listed in Annex I in the Member State in which the SUP is registered.

This Directive is without prejudice to any national laws governing matters outside its scope, such as matters related to labour law, posting of workers, workers' participation in the management or supervisory bodies of companies, right to information and consultation, taxation, accounting or insolvency proceedings. It is also without prejudice to the application of the national rules on the conflict of laws, EU rules on the prevention of the use of the financial system for the purpose of money laundering and terrorist financing.

The observation that this proviso is of a self-restricting nature and, as a consequence, that national law is 'creeping in' in the SUP Directive would be an understatement: the 2014 Proposal referring to 'national law' in its provisions 20 times already, the compromising text

63. EM 2014, p. 6 
2015 , even after (or because of?) the abolishment of several provisions, results in no less than 36 'hits'.

The first and quite serious flaw of this methodological approach is that the words "governed by national laws" are "clarified" (sic) by the Recital, adding that the reference to national law "... should also be without prejudice to the application of the national rules on the conflict of lams". 64

This addition means that, so many issues being left under the Directive's concept to national laws, to date courts of all Member States are offered considerable discretionary freedom to 'characterize' the nature of crossborder company disputes, even more in the awareness that so far there is hardly any European Private International Law to be applied to cross-border company law relationships. ${ }^{65}$ This observation is by no means made for mere academic exercise: pending in the CJEU is a case concerning a company merger operation giving rise to no less than seven preliminary questions having regard to the interpretation of secondary EU law covering EU Company Law Directives as well as the 'Rome I' and 'Rome II' EU Regulations just mentioned. ${ }^{66}$

But there is more to it. Apart from the applicable (national) law, there is furthermore the issue of crossborder civil and commercial proceedings raising difficulties. How to deal with, for example, (alternative) jurisdiction rules allowing the plaintiff to commence court proceedings in different EU Member States and, consequently, different (Common or Civil Law biased) characterizations by Member State courts of the issue at stake? ${ }^{67}$ Recent case law in the Court of Justice may illustrate what is likely to occur more often in the future: 10 September 2015, the CJEU had to interpret 'poor performance' of a limited liability company ${ }^{68}$ officer, notably in the light of the preliminary question whether any company action had to be initiated in the forum contractus (Article $5.1 \mathrm{ex}$, to date Article 7.1) or the forum delicti (Article $5.3 \mathrm{ex}$, to date Article 7.2) of the aforementioned 'Brussels I' EU Regulation. ${ }^{69}$ It is important that, once the forum delicti is endowed with jurisdiction, the 'harmful event' is usually linked to the company's 'real seat' (headquarters) and not its registered office. Difference in treatment, procedurally and

64. Compromising text 2015, Recital 10(a)

65. EU instruments like e.g. EU Directives 864/2007 ('Rome II') on the law applicable to non-contractual obligations and 593/2008 ('Rome I') on the law applicable to contractual obligations explicitly exclude company law matters from their substantive scope.

66. CJEU C-483-14 (KA Finanz AG v. Sparkassen Versicherung AG Vienna Insurance Group).

67. Intensified cross-border company relationships increasingly provoke preliminary stayings in the CJEU having regard to the position of companies in firms involved in cross-border civil proceedings. Cf. Rammeloo 2015 , p. 234 dealing with EU Regulation 1215/2012 on jurisdiction and recognition and enforcement of judgements in civil and commercial matters ('Brussels I bis') having replaced Regulation 44/2001, 10 January 2015

68. It is more than likely that in the future, the same judicature equally applies to private (and public) limited liability companies and SUPS, the latter business format after all deemed to be 'creature of national law' of the EU Member States.

69. CJEU C-47/14 (Holterman-Ferho). substantively speaking, may thus at the end of the day thwart the interest of a European 'level playing field'.

The SUP Directive therefore needs more guidance in the first place, and for the time being, from point of view of the 'applicable law' in a wide sense (i.e. without prejudice to the application of the national rules on the conflict of laws). Needed more than ever but still way beyond the horizon of EU lawmakers is a coherent 'interface' of complementary (secondary) EU legislation harmonizing matters of jurisdiction and applicable law, governing 'companies and firms' and SUPs alike, both in their essence remaining 'creatures of national law'. ${ }^{70}$

\section{The 2014 and the 2015 Draft Proposal Compared}

When compared to the 2014 Proposal for an SUP Directive, the 2015 compromising text for an SUP Directive has underwent quite considerable changes.

Some changes are of a gradual nature ( $c f$. registration period: from three to five days, maximum; digital long distance registration and protective measures for SUP counterparts). Others, however, are far more striking, notably provisions that altogether were abolished. Notably, Article 10 defining the formal scope of the proposed SUP Directive by referring to the company's 'seat' takes away basic guidance, needed to delimitate the cross-border functioning of the (future) SUP. This is a serious flaw, even more because of the fact that notably the importance of SUPs for cross-border business was underscored by the Commission.

A second setback is the deletion of provisions concerning fundamental powers of the general meeting ( $c f$. Article 21 on the general meeting's power in the resolution making process; Article 23 concerning the power to instruct other company bodies, in particular the SUP's management board, and Article 24 on company representation). This curtailment has consequences for the functioning of both stand-alone SUPs as well as for SUPs embedded in a 'vertical' corporate group or 'horizontal' 'chain' structures.

As versatile issues already fell out of the substantive scope of the 2014 Proposal (employment, insolvency, tax law, etc.), the referrals to 'national law' even increased to 36 in the 2015 Proposal. Moreover, is it not always clear in how far these references to 'national law' include or exclude conflict of law rules?

\section{Conclusions}

It is time for an overall perception of the proposed EU SUP Directive, in particular the compromising text ver-

70. A 'European Single Rulebook' for company law could be a suitable 'interface' for the harmonization of various EU law instruments dealing with company law matters. 
sion of May 2015. The Proposal deserves approval for several reasons: the SUP can be set up and registered swiftly, in digital manner, even 'at a distance', physical attendance of the company founder not being required; neither is there any minimum capital nor (other) reserve; use of the SUP is not in advance excluded for company groups or chain structures; the SUP provides for an European 'template', creating more 'trust'; though meant to serve SMEs, no 'maximum' size restrictions are imposed on the SUP.

But the legislative shortcomings cannot be overlooked. Digitalized registration of the SUP, notably in a 'long distance' context, may provoke abuse and discourage contractors (businessmen and consumers alike) to enter in transactions with a 'remote' SUP but also of 'hijacking' of the SUP by alleged (but of course unauthorized) 'company officers'; the abolishment, not only of Article 10 having regard to the SUP's seat but of many other provisions that substantively and autonomously regulated competences and liabilities of both stand-alone operating SUPs and SUPs embedded in a company group structures, may well leave the business world with the impression of an empty shell. Last but not least, the overwhelming number of provisions leaving matters to national laws of the Member States (even including conflict of law rules opening the door to diverging characterizations by Member States' courts) creates a false image of a genuinely 'European' company business format. Needed more than ever, but still way beyond the horizon of EU lawmakers, is a coherent 'interface' of complementary (secondary) EU legislation harmonizing matters of jurisdiction and applicable law, governing 'companies and firms' and SUPs alike, both in their essence remaining 'creatures of national law'.

\section{Bibliography}

J. Bouchourevliev, "Pour une sàrl Européenne", 1973 (conference).

G. Herberstein, Die GmbH in Europa, Zürich, SChulthess Verlag, 2001.

H. Hirte \& C. Teichmann (eds.), The European Private Company - Societas Privata Europaea (SPE), Berlin/Boston, ECFR De Gruyter, 2013.

P. Hommelhoff, "Die SUP-Ferngründung", in $Z G R$ special issue, 2015 , pp. 69-88.

D. Leuering, "SUP - Perspektiven für die Praxis", in ZGR special issue, 2015, pp. 89-110.

M. Lutter \& J. Koch (eds.), Societas Unius Personae (SUP), in ZGR special issue, Berlin/Boston, 2015.

OECD, "Top Barriers and Drivers to SME Internationalisation", Report by the OECD Working Party on SMEs and Entrepreneurship, OECD, 2009.

S. Rammeloo, "Law Reform on Cross-Border Civil Procedure in Europe: 'Companies and Firms' under EU Regulation 1215/2012", ECL, 2015, pp. 234-244.

P. Ries, "Die SUP und das Handelsregister", in $Z G R$ special issue, 2015, pp. 65-68.

J. Schmidt, "Die SUP aus Sicht der Kommission ubnd ihr Kapitalschutz", in ZGR special issue, 2015, pp. 1-22.
G. Sǿgaard, Introduction of a Group Definition in the Nem Accounting Directive: The Impact on Future Accounting Regulation, ECL, 2014, pp. 232-236.

C. Teichmann, "Einsatzmöglichkeiten der Societas Unius Persona", in ZGR special issue, 2015, pp. 37-64.

I. Wuisman, The Societas Unius Personae, ECL, 2015, p. 34.

D.F.M.M. Zaman et al. (eds.), The European Private Company (SPE): A Critical Analysis of the EU Draft Statute, Antwerp, Intersentia, 2009. 